\title{
MATHEMATICAL MODELING OF A SI ENGINE CYCLE WITH ACTUAL AIR-FUEL CYCLE ANALYSES
}

\author{
Perihan Sekmen $^{\mathrm{a}}$, Yakup Sekmen ${ }^{\mathrm{b}}$ \\ ${ }^{a}$ Department of Mechanical Education, Technical Education Faculty, Karabuk \\ University, Karabuk, Turkey.perduranli@yahoo.com \\ ${ }^{\mathrm{b}}$ Department of Automotive, Vocational College, Karabuk University, Karabuk, \\ Turkey.
}

\begin{abstract}
The performance of an engine whose basic design parameters are known can be predicted with the assistance of simulation programs into the less time, cost and near value of actual. However, inadequate areas of the current model can guide future research because the effects of design variables on engine performance can be determined before. In this study, thermodynamic cycle and performance analyses were simulated for various engine speeds $(1800,2400$ ve 3600 1/min) and various excess air coefficients (EAC) (0.95-1.05) to crank shaft angle (CA) with 1 degree increment at full load and 8:1 constant compression ratio (CR) of a SI engine with four stroke, single cylinder and natural aspirated. Brake mean effective pressure, power, thermal efficiency, specific fuel consumption ( $\mathrm{sfc}$ ), etc engine performance parameters were calculated; the values of peak cylinder pressures and temperatures and positions of them were determined by the present program. Variations of these parameters with crank angle, engine speed and excess air coefficient were presented graphically. The calculated results show good agreement with literature. Simulation program is usable to set for varies load, compression ratios, and engine sizes.
\end{abstract}

Keywords: Spark Ignition (SI) engine, Air-fuel cycle, Excess Air Coefficient (EAC)

\section{INTRODUCTION}

Researchers have been spending essential effort to improve the performance of SI engines and about internal combustion engines (ICE) they have been practiced on both empirical and theoretical methods. Although the empirical methods result real outcomes; the design, production and test of the new engines and systems cost more than the theoretical models and need more time. The mathematical model of an engine cycle could be estimated almost true with a computer program depending on real rights [1-12]. Generally, mathematical engine simulations are practice in two ways, which are fluid dynamic based and thermodynamic based models. Thermodynamic cycle models are based on the thermodynamic analysis of the content of cylinder during the engine cycle. In these models, the $1^{\text {st }}$ law of thermodynamics is applied to open system of airfuel and residual gas mixture into the manifolds and cylinders and it is zero dimensioned. Therefore, the equations leading the model are made of basic differential equalities [2,13]. Besides, due to a mathematical modeling performed successfully, analysis periods become shorter, the cost is obtained more efficiently. By the solution of mathematical model, change in performance is researched as each of the engine parameters changed as wanted, it is possible to determine the engine characteristics. Therefore empirical works on engines that give positive results can be performed $[1,14]$. 
As a result, benefits of simulation can be summarized in two groups. Firstly, by a model tested of accuracy performance of an engine that basic design parameters of it are given can be determined. The values obtained are useful in order to shorten testing of the results expected from engine design and to help the designer to pre-determine the possible effects of various design changes. As for the second one is to determine the data yet reached and the areas that data is insufficient.

In this study, the operating characteristics of a single cylinder, natural aspirated, SI engine that works according to actual air-fuel Otto cycle is analyzed theoretically. The simulation program is prepared by paying attention to advance depending on engine speed, combustion duration to excess air coefficient, humidity in air, dissociation and variable specific heats. In addition, compression and expanding processes are not decided as adiabatic during simulation of cycle and pressure change in cylinder, the calculations of gas flow through into intake valve and out to exhaust valve are performed.

\section{COMPUTER PROGRAM and MATHEMATICAL MODEL}

The operating parameters of single cylinder natural aspirated SI engine are analyzed according to the Otto cycle which the specifications are given in Table 1 . In the established mathematical model, pressure and temperature of cylinder gas and composition of combustion products are calculated using the empirical equations. Ignition timing is optimized to obtain the best performance according to theoretical cycle and determined as $25^{\circ} \mathrm{CA}$ bTDC for $2400 \mathrm{l} / \mathrm{min}$ engine speed. While the ignition advance is changed by the engine speed, combustion duration is varied with EAC $[12,15,16]$. Thus, because the mixture with $0.95 \mathrm{EAC}$ is accepted as the fastest burning mixture, combustion duration is decided as $50^{\circ}$ CA [15,17-19]. The combustion duration is increased because the flame speed decreases for the mixtures in which EAC is less and greater than 0.95 . Besides, acceleration of the engine speed would accelerate the turbulence inside the clearance volume and flame speed it would result with shortening the combustion duration as a time.

Table 1. Technical specification of modelled SI engine.

\begin{tabular}{|l|l|}
\hline Cylinder diameter (D) & $88 \mathrm{~mm}$ \\
\hline Cylinder number & 1 \\
\hline Stroke (S) & $80 \mathrm{~mm}$ \\
\hline Connection rod lengths (LB) & $128 \mathrm{~mm}$ \\
\hline Intake valve opening & $10^{\circ} \mathrm{CA}$ before Top Dead Center (bTDC) \\
\hline Intake valve closing & $30^{\circ} \mathrm{CA}$ after Bottom Dead Center (aBDC) \\
\hline Exhaust valve opening & $50^{\circ} \mathrm{CA}$ before Bottom Dead Center (bBDC) \\
\hline Exhaust valve closing & $10^{\circ} \mathrm{CA}$ after Top Dead Center (aTDC) \\
\hline
\end{tabular}

Therefore, the engine speed is also considered in calculating the combustion duration. The ignition advance of the model engine is considered as $20^{\circ} \mathrm{CA}$ bTDC, $25^{\circ} \mathrm{CA}$ bTDC and $32.5^{\circ} \mathrm{CA}$ bTDC for $18001 / \mathrm{min}, 24001 / \mathrm{min}$ and $33001 / \mathrm{min}$ engine speeds respectively [15]. 
A computer program is written on FORTRAN program for the presented mathematical cycle model [20,21]. The air-fuel mixture drawn into engine cylinder under atmospheric pressure and temperature conditions are filled into engine cylinder with the residual gas left inside the cylinder from previous cycle and pressure and temperature of the last mixture is changed. First thermodynamic properties of this mixture are determined. In combustion model, clearance volume is supposed as composed of three regions which are "burned region", "burning region", "unburned region" and compression, combustion and expansion processes are calculated with the help of thermodynamic relations. The gas pressure and temperature and the composition of combustion products are calculated step by step using thermodynamic equations. The equations are solved with Newton Raphson iteration method until the temperature values approaching each other with $1 \mathrm{~K}$ tolerance at the end of calculating step of compression and expansion processes. And then engine performance values such as engine power, specific fuel consumption, mean effective pressure, thermal efficiency are obtained.

Cylinder volume: Firstly, design (cylinder diameter, stroke, compression ratio, connecting rod length, diameter of intake and exhaust valves, and their opening advance and closing timing values and operating parameters (engine speed, universal gas constant, intake air pressure and temperature values, exhaust opposite pressure and temperature, flow coefficient of intake and exhaust, specific heat at constant pressure, excess air coefficient, ignition advance, end of combustion point, calorific value of fuel, relative humidity and saturation pressure of intake air, atmospheric pressure and temperature, reference pressure and temperature etc.) were read from date file. And then piston surface area, swept volume and combustion chamber volume were calculated.

Air-fuel characteristics: In the program, constant input data and engine constructive properties were initially read from a folder opened in the program, whereas the properties of $\mathrm{O}_{2}, \mathrm{~N}_{2}, \mathrm{CO}, \mathrm{CO}_{2}$, and $\mathrm{H}_{2} \mathrm{O}$ were read from three different polynomial files for two different temperature range $(300-1000 \mathrm{~K}$ and $1000-5000 \mathrm{~K})$. In the model developed, variations of pressure and temperature, specific fuel consumption, power output, thermal efficiency etc. parameters for 8:1 compression ratio, and various EAC and engine speeds are calculated and recorded into data files opened in the program separately.

Heat Transfer: It was assumed that the heat conduction coefficient is a function of engine speed and crank angle and the heat transfer from the combustion chamber to the cooling water temperature of which was assumed to be constant are defined as Equation $1[15]$.

$\mathrm{h}=\frac{\mathrm{ES}}{40} \cdot\left(1000-5000 \cdot \operatorname{Cos}\left(\frac{\theta}{2}-10\right)\right) \quad$ ve $\quad \mathrm{Q}=\mathrm{h} \cdot \mathrm{A}_{\mathrm{S}} \cdot\left(\mathrm{T}-\mathrm{T}_{\mathrm{S}}\right)$

Where;

h : Convection heat transfer coefficient $A_{S}:$ instantaneous surface area $\left(\mathrm{m}^{2}\right)$ $\left(\mathrm{kJ} / \mathrm{m}^{2} \mathrm{~h}^{\circ} \mathrm{C}\right)$,

ES : engine speed as $1 / \mathrm{s}, \quad \mathrm{T}:$ instantaneous gas temp. $(\mathrm{K})$

$\theta \quad:$ instantaneous crank shaft angle $\left({ }^{\circ} \mathrm{CA}\right), \quad \mathrm{T}_{\mathrm{S}}:$ average surface temp. (350K) 
Determination of thermodynamic properties of reactants and products: With the variations of the internal energy and specific heat values [Equations 2 and 3] of the fuel were determined by a sub-program according to the temperature up to the end of combustion period, and the variations of the internal energy and specific heats of mixture throughout the cycle were determined by another program. Thus the total internal energy of the gas mixture containing species from $\mathrm{i}=1$ to $\mathrm{N}$ and fuel, $\mathrm{E}(\mathrm{T})(\mathrm{kJ})$, can be written as;

$$
E(T)=R_{m o l} \cdot\left[\sum_{i=1}^{N} N_{i} \cdot\left[\left(\sum_{j=1}^{5} u_{i j} \cdot \frac{T^{j}}{j}+u_{i 6}\right)-T\right]+N_{7} \cdot\left[\left(\sum_{j=1}^{4} u_{7 j} \cdot \frac{T^{j}}{j}-\frac{u_{75}}{T}+u_{76}\right)-T\right]\right]
$$

where, $\mathrm{N}_{\mathrm{i}}$ is the mole number of $\mathrm{i}$ gas from the species constituting the mixture and $\mathrm{N}_{7}$ and $\mathrm{n}_{\mathrm{m}}$ are the mole number of the fuel in the mixture and the total mole number of the mixture respectively $[22,23]$. Specific heat of the mixture at constant volume, $\mathrm{C}_{\mathrm{V}}(\mathrm{T})$ $(\mathrm{kJ} / \mathrm{kmol}-\mathrm{K}), \mathrm{C}_{\mathrm{V}}(\mathrm{T})=\frac{\mathrm{de}(\mathrm{T})}{\mathrm{dT}}$, is written as follows;

$$
\mathrm{C}_{\mathrm{V}}(\mathrm{T})=\frac{\mathrm{R}_{\mathrm{mol}}}{\mathrm{n}_{\mathrm{m}}} \cdot\left[\sum_{\mathrm{i}=1}^{\mathrm{N}} \mathrm{N}_{\mathrm{i}} \cdot\left[\left(\sum_{\mathrm{j}=1}^{5} \mathrm{u}_{\mathrm{ij}} \cdot \mathrm{T}^{\mathrm{j}-1}\right)-1\right]+\mathrm{N}_{7} \cdot\left[\left(\sum_{\mathrm{j}=1}^{4} \mathrm{u}_{7 \mathrm{j}} \cdot \mathrm{T}^{\mathrm{j}-1}+\frac{\mathrm{u}_{75}}{\mathrm{~T}^{2}}\right)-1\right]\right]
$$

When this equation is multiplied by the Universal gas constant $\left(\mathrm{R}_{\mathrm{mol}}(\mathrm{kJ} / \mathrm{kmol}-\mathrm{K})\right)$, various algorithms have been developed to calculate the specific heat and internal energy values of species and fuels ("i" for species and 7 for fuel were used as subindices) [22-24]. $\mathrm{u}_{\mathrm{ij}}$, which is used in these equations represents the polynomial coefficients for 6 species, and the polynomial coefficients of reactants between 300 and $1000 \mathrm{~K}$ of temperatures were used in the calculation of the properties of unburned mixture, and the polynomial coefficients of species between 1000 and $5000 \mathrm{~K}$ of temperatures were used in the calculation of the properties of burned mixture [14,25].

Combustion: The mass of the fuel burned, $\mathrm{m}_{\mathrm{y}}$, pressure and temperature values in every $1^{\circ}$ of crankshaft rotation were calculated by using Wiebe function in a subprogram, Eq. 4. Because the amount of heat released during the incomplete combustion in a SI engine is less than the heat capacity of air-fuel mixture, combustion efficiency was taken into consideration for EAC values less than 1 during the calculation of the current model. A different sub-program was used to calculate the amount of burned fuel at each step and it was assumed that all the fuel has been burned completely in the end of combustion period $[1,6,15,18,26,27]$.

$\mathrm{m}_{\mathrm{y}}=1-\operatorname{EXP}\left(-6.908 \cdot\left(\frac{\theta-\theta_{\mathrm{IA}}}{\Delta \theta_{\mathrm{C}}}\right)^{\mathrm{m}+1}\right)$

Where;

$\theta_{\mathrm{IA}}:$ Ignition advance $\left({ }^{\circ} \mathrm{CA}\right) ; \mathrm{m}=3$

$\Delta \theta_{\mathrm{C}}:$ Combustion duration $\left({ }^{\circ} \mathrm{CA}\right)$ 
Products of partial incomplete combustion (PIC) were calculated by using a subprogram prepared with the lean mixture conditions $(\mathrm{EAC} \geq 1.0)$. EAC value greatly changes the flame temperature. Flame temperature in lean mixtures is relatively low due to lower amounts of fuel and chemical energy to be converted to heat energy [4]. $\mathrm{CO}_{2}$ and $\mathrm{H}_{2} \mathrm{O}$ are converted to products of incomplete combustion such as $\mathrm{CO}$ and $\mathrm{H}_{2}$ by high temperature causing thermal cracking at the lean mixture region. These products of incomplete combustion are observed in the exhaust gas since they don't have the time required for re-combining reactions. Equilibrium constants are used in the calculation of PIC products $[7,9,10,15,28]$. Products of incomplete combustion (IC) were calculated by using equilibrium reaction constant of water-gas in a sub-program prepared for the condition of operating on rich mixture $(\mathrm{EAC}<1.0)$. Higher flame temperatures produced in combustion with rich mixture provide a faster flame speed but production of $\mathrm{H}_{2} \mathrm{O}$, $\mathrm{CO}, \mathrm{CO}_{2}$, and $\mathrm{H}_{2}$ in rich mixture region, at which there is a lack of oxygen in the products of combustion leading to incomplete combustion (IC), decrease the heat energy thus reducing the flame temperature and flame speed. There is an equilibrium condition among the combustion products depending on the temperature and the time period they stay in the combustion chamber. These thermal dissociation reactions (Eq. 5 and 8) and equilibrium constant reactions (Eq. 6,7 and 9) for lean and rich mixtures are;

$$
\begin{aligned}
& \mathrm{CO}+1 / 2 \mathrm{O}_{2} \Leftrightarrow \mathrm{CO}_{2} \\
& \mathrm{H}_{2}+1 / 2 \mathrm{O}_{2} \Leftrightarrow \mathrm{H}_{2} \mathrm{O} \\
& \log _{10} \mathrm{~K}_{\mathrm{CO}_{2}, \mathrm{~T}}=68.05-133.91565 \cdot 10^{-3} \cdot \mathrm{T}+121.32033 \cdot 10^{-6} \mathrm{~T}^{2} \\
& -57.78299 \cdot 10^{-9} \cdot \mathrm{T}^{3}+13.87067 \cdot 10^{-12} \cdot \mathrm{T}^{4}-1.13321331 \cdot 10^{-15} \cdot \mathrm{T}^{5} \\
& \log _{10} \mathrm{~K}_{\mathrm{H}_{2} \mathrm{O}, \mathrm{T}}=59.787-11.4581 \cdot 10^{-2} \cdot \mathrm{T}+10.33065 \cdot 10^{-5} \mathrm{~T}^{2} \\
& -4.91 \cdot 10^{-8} \cdot \mathrm{T}^{3}+1.1773 \cdot 10^{-11} \cdot \mathrm{T}^{4}-0.11208 \cdot 10^{-14} \cdot \mathrm{T}^{5} \\
& \mathrm{H}_{2}+1 / 2 \mathrm{O}_{2} \rightarrow \mathrm{H}_{2} \mathrm{O} \\
& \mathrm{C}+1 / 2 \mathrm{O}_{2} \rightarrow \mathrm{CO} \\
& \mathrm{C}+\mathrm{O}_{2} \rightarrow \mathrm{CO}_{2} \\
& \log _{10} \mathrm{~K}_{\mathrm{WG}}=-8,2028+19,07961 \cdot 10^{-3} \cdot \mathrm{T}-17,6397 \cdot 10^{-6} \cdot \mathrm{T}^{2} \\
& +8,43868 \cdot 10^{-9} \cdot \mathrm{T}^{3}-2,026 \cdot 10^{-12} \cdot \mathrm{T}^{4}+0,193013 \cdot 10^{-15} \cdot \mathrm{T}^{5}
\end{aligned}
$$

\section{RESULTS AND DISCUSSION}

For mathematical modeling of the SI engine, first the engine performance parameters ( $\mathrm{Sfc}, \mathrm{Pe}, \mathrm{P}_{\mathrm{me}}$, thermal efficiency) and the variations of engine pressure and temperatures according to CA for $0.95,1.0$, and 1.05 EAC values at $2400 \mathrm{l} / \mathrm{min}$ of engine speed and 8:1 compression ratio were determined, and then the same operations were conducted for 1800,2400 , and $3300 \mathrm{l} / \mathrm{min}$ engine speeds with an EAC value ranging from 0.8 to 1.1 by an increment of 0.05 . 
- Cylinder pressure and temperatures

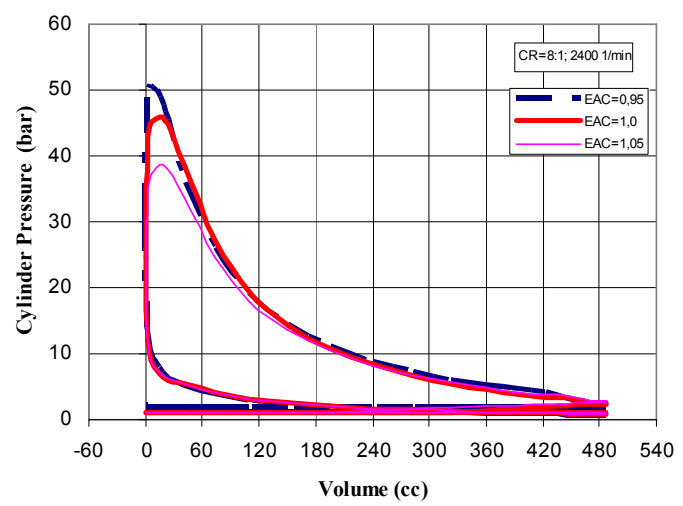

The cylinder pressure variation versus the cylinder volume throughout a complete cycle is shown in Fig. 1. As the cylinder pressure and net work area of the diagram is increased by enriching the air-fuel mixture $[6,17,18,29]$, it is observed that maximum cylinder pressure was increased from 38 bar to 50 bar as the EAC is reduced from 1.05 to 0.95 .

Fig. 1. The effect of EAC on cylinder pressure

The variations of cylinder pressures, maximum cylinder pressures and the positions of their maximum values versus CA throughout the combustion period were shown in Figure 2 with different EACs, and in Figure 3 with different engine speeds. As the EAC was increased from 0.95 to 1.05 , maximum pressure was reduced from 52 bar to 40 bar and it's position of maximum values are moved from $13^{\circ} \mathrm{CA}$ to $16^{\circ} \mathrm{CA}$ aTDC i.e. the maximum pressure was occurred $3^{\circ} \mathrm{CA}$ later. Both the cylinder pressure and temperature values increase and their peak values become earlier due to shortened the heat transfer period, ignition delay and combustion period by the increasing engine speed. As a result, it is observed that the maximum cylinder pressure is increased from about 46.4 bar to 59.6 bar and is occurred $10^{\circ} \mathrm{CA}$ earlier by rising engine speed from $18001 / \mathrm{min}$ to $33001 / \mathrm{min}$.

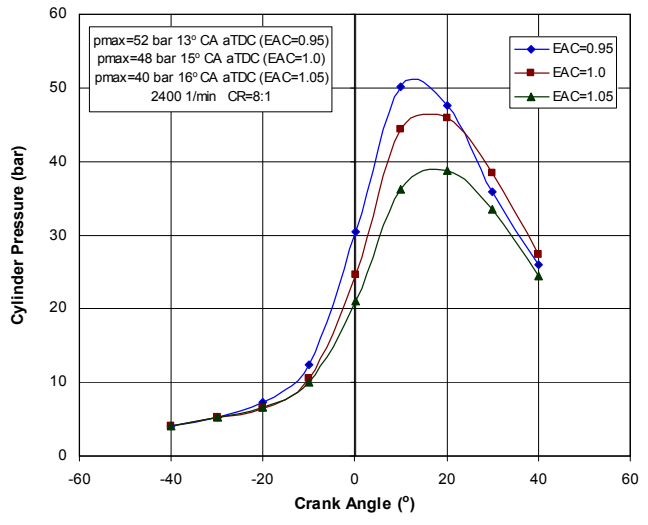

Fig. 2. The effect of EAC on pressure

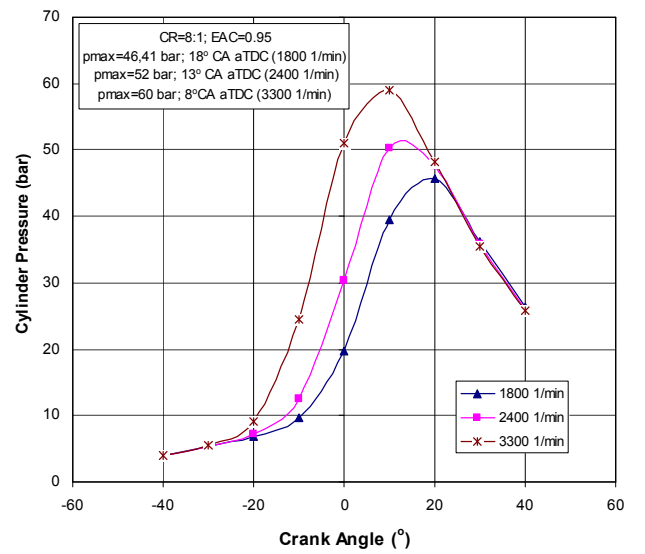

Fig. 3. The effect of engine speed on pressure

The variations of cylinder temperature and the position of maximum temperature with respect to CA during combustion period were shown in Fig. 4 with EAC and in Fig. 5 with engine speed. When EAC increased from 0.95 to 1.05 , maximum cylinder temperature is reduced from $2771 \mathrm{~K}$ to $2553 \mathrm{~K}$, and it is occurred $4^{\circ} \mathrm{CA}$ later. The 
mixture with $0.95 \mathrm{EAC}$ is assumed to be the fastest burning mixture. Combustion period is increased due to reduced flame speed for EACs less and more than $0.95[15,19,30]$. Maximum cylinder gas temperature and pressure values for combustion with rich mixtures are higher than that of leaner mixtures, and also combustion rates of rich mixtures are lower combustion durations are longer and thus the maximum pressure and temperature values occur later. For $1.05 \mathrm{EAC}$ as the engine speed is changed from 1800 $1 /$ min to $33001 /$ min maximum cylinder temperatures are increased from $2500 \mathrm{~K}$ to $2661 \mathrm{~K}$ and occurred $12^{\circ} \mathrm{CA}$ earlier.

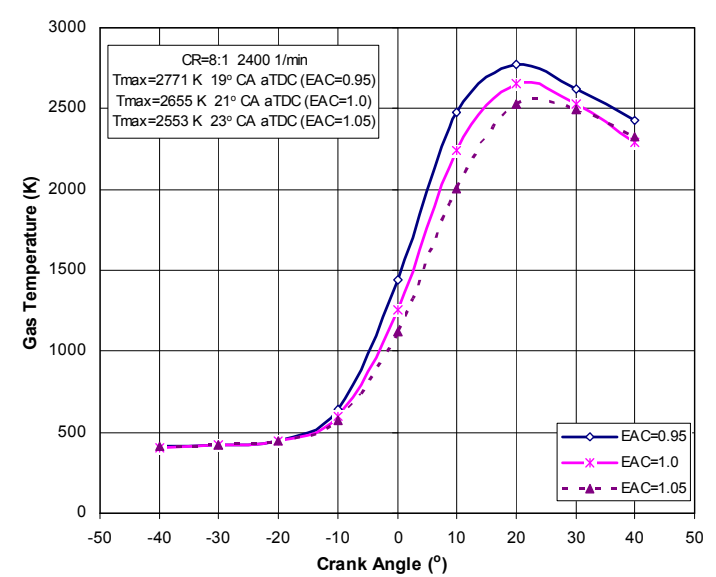

Fig. 4. The effect of EAC on cylinder gas temperature

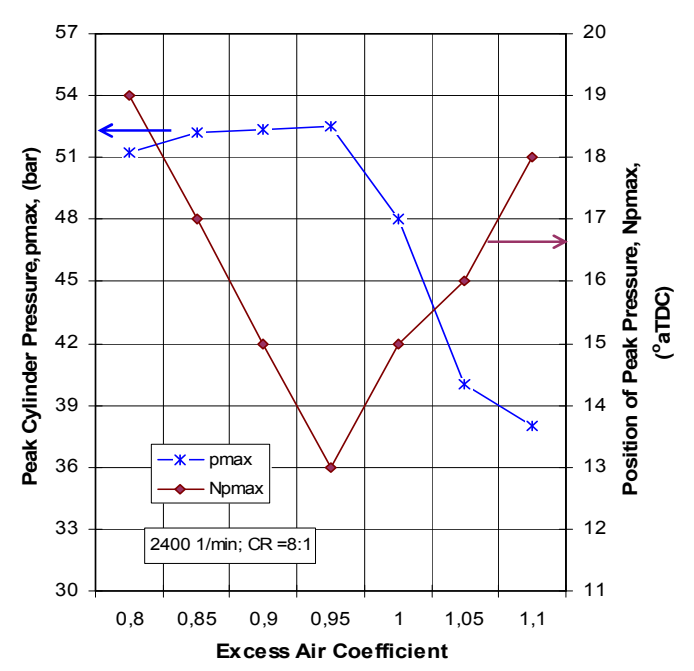

Fig. 6. The effect of EAC on peak pressure

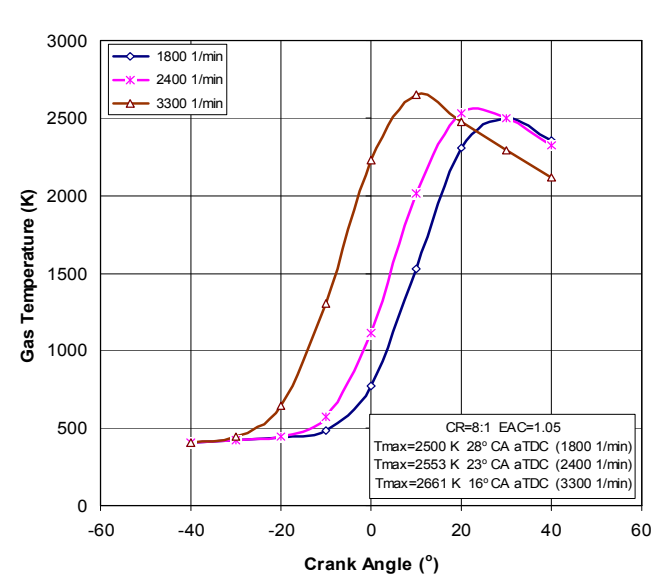

Fig. 5. The effect of engine speed on cylinder gas temperature

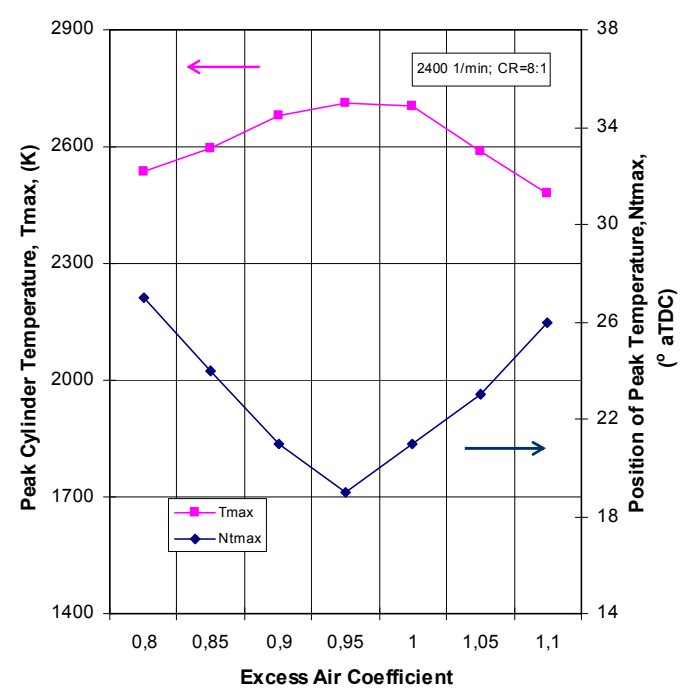

Fig. 7. The effect of EAC on peak pressure

Figure 6 and 7 present the variations of maximum cylinder pressures and temperatures and their positions with EAC. To the leaner and richer mixtures from the mixture with 0.95 of EAC' combustion durations are longer due to decreased flame speed. However, maximum cylinder gas temperature and pressure values with rich mixtures are higher than those of with lean mixtures. Also the combustion duration of rich mixtures are 
longer and the points of maximum temperature and pressure are later accordingly. According to these results, it was determined that, as the EAC is raised from 0.8 to 1.1, the peak cylinder pressures and temperatures decreased from 51 bar to 38 bar and from $2536 \mathrm{~K}$ to $2481 \mathrm{~K}$ respectively. And then both of their values are occurred $1^{\circ}$ earlier.

- Brake Power $\left(P_{e}\right)$ and mean effective pressure $\left(\mathbf{p}_{\mathrm{me}}\right)$ : Because the combustion duration is lengthened due to decreasing combustion speed as the mixture becomes richer, the maximum pressure and temperature values becomes higher but they occur later. It is assumed that the maximum combustion rate and thus the shortest combustion duration occur at a mixture slightly richer than the stoichiometric (EAC of 0.95) and the maximum heat input is at a mixture $20 \%$ richer than stoichiometric mixture i.e. at EAC of 0.80 . For this reason, the mixture with $0.8 \mathrm{EAC}$ for all engine speeds is the mixture at which the mean effective pressure and maximum effective power is obtained, and these values decrease as the mixture becomes lean as of this EAC value [15,17,31,32]. Engine produces its maximum power at an engine speed, at which the power increase provided by the frequency of cycles is completely balanced by the decrease in moment. In this situation the cylinders take in a maximum amount of mixture per second. However, the engine power decreases at higher speeds because the increase in engine speed can not compensate the decrease in moment. As shown in Fig. 8, the maximum effective power decreases from $11.7 \mathrm{~kW}$ to $10.9 \mathrm{~kW}$ with a reduction of $7 \%$ when EAC is increased from 0.8 to 1.1 at $3300 \mathrm{l} / \mathrm{min}$ of engine speed. Thus, engine speed affects the effective power positively, whereas the increase of EAC affects negatively. Mean effective pressure has a maximum value at a specific engine speed, and it decreases at higher speeds due to a reduction in volumetric efficiency. According to this result, it was observed that the maximum mean effective pressure values decrease from 11.65 bar to 10.19 bar with a reduction of $12.55 \%$ when EAC is increased from 0.8 to 1.1 (2400 $1 / \mathrm{min})$.

- Thermal efficiency, $\boldsymbol{\eta}_{\text {th }}$ ve specific fuel consumption, Sfc: Thermal efficiency increases as the mixture becomes leaner because the mixture's properties approach to those of ideal gas. Minimum and maximum thermal efficiencies are determined as 33\% for $0.8 \mathrm{EAC}$ and $3300 \mathrm{l} / \mathrm{min}$ of engine speed, and $37 \%$ for $1.1 \mathrm{EAC}$ and $2400 \mathrm{l} / \mathrm{min}$ of engine speed (minimum specific fuel consumption speed) respectively. When the engine speed was increased from $1800 \mathrm{1} / \mathrm{min}$ to $3300 \mathrm{1} / \mathrm{min}$ for 1.1 of EAC, the maximum thermal efficiency decreased from $37 \%$ to $30 \%$. Besides, specific fuel consumption represents the opposite of the variation in volumetric efficiency by engine speed $[9,10,33,34]$. Specific fuel consumption decreases by increasing EAC at all engine speeds. According to this result, it was observed that the minimum specific fuel consumption decrease from $249.21 \mathrm{~g} / \mathrm{kWh}$ to $208.418 \mathrm{~g} / \mathrm{kWh}$ with a reduction of $16.4 \%$ when EAC is increased from 0.8 to 1.1 at 2400 1/min engine speed, Fig. 9. 


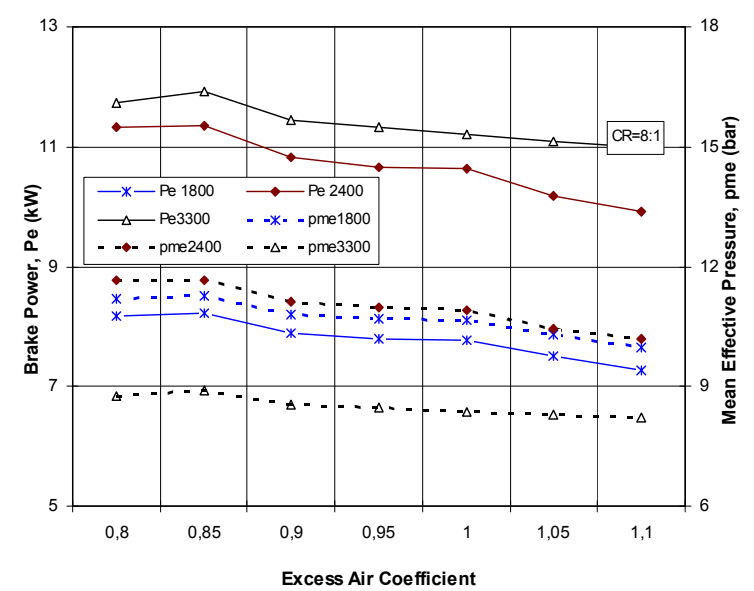

Fig. 8. The variation of brake power and mean effective with EAC

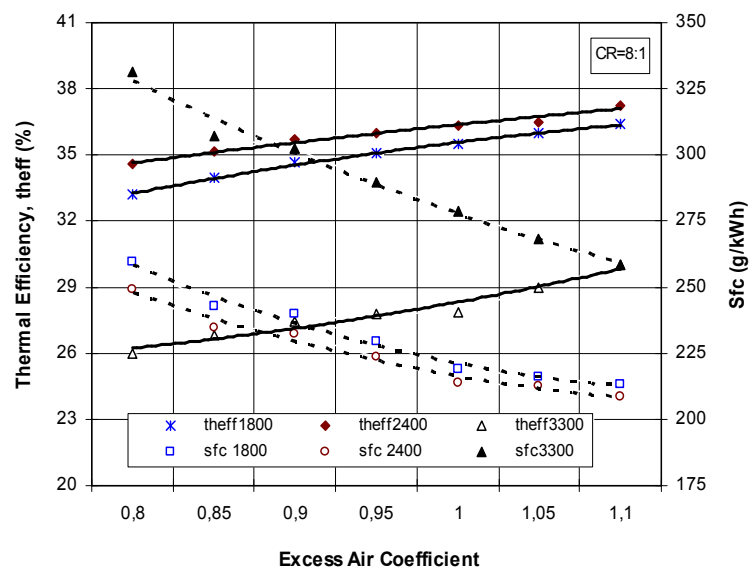

Fig. 9. The effect of EAC on thermal efficiency and specific fuel consumption

\section{CONCULUSIONS}

In this study, a mathematical simulation model is developed in FORTRAN programming language in order to investigate the cycle analysis of a single cylinder four stroke engine working according to naturally aspirated Otto cycle. When the program is run, the following results were observed;

- The maximum cylinder pressure and temperature increase by the engine speed, the peak values of mean effective pressure and thermal efficiency are obtained at 2400 $1 /$ min of engine speed and then they begin to decrease, effective power increase by the engine speed up to the maximum engine speed and then decrease

- Cylinder pressure and temperatures, mean effective pressure, effective power, and specific fuel consumption decrease as the EAC is increased (between 0.95 and 1.1 with 0.05 increments), and then it was seen that as the mixture becomes leaner since the mixture approaches to the ideal gas properties thermal efficiency increase

- The program is capable of being used with alternative fuels and making performance comparisons thanks to being able to change the cylinder sizes and numbers, and the cylinder inlet conditions. And however, program is suitable for making a study by adding compression ratio, exhaust gas recirculation (EGR) and exhaust emissions, and variable throttle position.

\section{REFERENCES}

1. Ö. Öğüçlü, Thermodynamics Model of The Cycle of SI Engine, Msc Thesis, Graduate School of Natural And Applied Sciences of Dokuz Eylül University, İzmir, 1-9 1998.

2. H. Bayraktar, O. Durgun, Mathematical modeling of SI Engine cycles, Energy Sources, 25, 439-445, 2003.

3. S. Nişli, Development of a Digital Computer Program for The Power Cycle and Pollutant Formation in Spark Ignited Engines, Msc Thesis, Metu Graduate School of Natural And Applied Sciences, Ankara, 1-10, 1982. 
4. U. Etiz, Simulation of The Combustion Process In A SI Engine On a Personal Computer, MSc Thesis, Metu Graduate School of Natural And App. Sciences, Ankara, 1-9, 1994

5. D.J. Patterson, A Comprehensive Cycle Analysis And Digital Computer Simulation For Spark-Ignited Engines, PhD Thesis, The University of Michigan, 1-10, 1962.

6. G.H. Abd Alla, Computer Simulation of a Four-Stroke SI Engine, Energy Conv.\&Management, 43, 1043-1061, 2002.

7. M. Balc1, Dört Zamanlı Türboşarjlı Direk Püskürtmeli Bir Dizel Motorunun Bilgisayar Ile Simülasyonu, Dok. Tezi, GÜ. Fen Bil. Enst. Ankara, 232-238, 1986.

8. S. Çetinkaya, Dört-Zamanlı Buji İle Ateşlemeli Bir Motor Performansının Bilgisayar Yardımıla Simülasyonu, Dokt. Tezi, GÜ. Fen B. Enst., Ank.,1-30, 1987.

9. P. Erduranlı, Buji Ile Ateşlemeli Tek Silindirli Değişken Sikıştırma Oranlı Bir Motorun Teorik Simülasyonu, Dokt. Tezi, GÜ. Fen B. Enst., Ankara, 40-112, 2003.

10. P. Erduranlı, Y. Sekmen, H.S. Yücesu, C. Çınar, Buji Ile Ateşlemeli Motorlarda Sıkıştırma Oranının Motor Performansına Etkisinin Gerçek Hava-Yakıt Çevrim Analizi Ile Incelenmesi, 8th International Combustion Symposium, 112-124, 2004.

11. P. Erduranl, A. Koca, Y. Sekmen, Performance Calculation Of A SI Engine According To The Ideal Air-Fuel Cycle Analysis, G̈̈. Fen Bil. Dergisi, 18(1), 103-114, 2005.

12. J. Ma, Y. Su, Y. Zhou, Z. Zhang, Simulation And Prediction On The Performance Of A Vehicle's Hydrogen Engine, Int. J. of Hydrogen Energy, 28, 77-83, (2003).

13. Z. Şahin, Benzin Motoru Çevrimlerinin Bilgisayar Modellemesi, Yüksek Lisans Tezi, KTÜ Fen Bil. Enstitüsü, Trabzon, 1-20, 1996.

14. J.B. Heywood, ICE Fundamentals, Mc Graw Hill Book Co., USA., 123-141, 1988.

15. T. Özaktaş, Benzin ve Doğalgaz Motorunun Çevrim Analizinin Matematiksel Model ile Karşılaştırılması, Dok. Tezi, İTÜ Fen Bil. Enstitüsü., İstanbul, 1-30, 1988.

16. J.A.A. Yamin, Comparative Study Using Hydrogen And Gasoline As Fuels: Combustion Duration Effect, Int. J. of Energy Research, 30, 1175-1187, 2006.

17. P.G. Blair, Design And Simulation Four Stroke Engines, SAE Inc., USA, $95-$ 110; 421-442, 1999.

18. P.G. Blair, Design And Simulation Two Stroke Engines, SAE Inc., USA, 297309; 343-346, 1999.

19. Heisler H., Advanced Engine Tech., Edward Arnold Press, London, 153-171, 1995.

20. Z. Altaç, İ. Gürkan, Mühendisler İçin Fortran Programlama, Osmangazi Üniversitesi Yayını, Eskişehir, 157-180, 1995.

21. J.H. McCormick, M.G. Salvadori, Numerical Methods In Fortran, Prentice Hall, UK, 150-185, 1964. 
22. E.L. Keating, Applied Combustion, Marcel Dekker Inc., New York, USA, 23-53, 83-90, 367-391, 1993.

23. R.S. Benson, N.D. Whitehouse, Internal Combustion Engines, Vol. 1, Pergamon Press, UK, 27-47, 1979.

24. R.S. Benson, N.D. Whitehouse Internal Combustion Engines, Volume 2, Pergamon Press, UK, 305-321, (1979).

25. D.R. Stull, E.F. Westrum, G.C. Sinke, The Chemical Thermodynamics of Organic Compounds, JW \& Sons Inc., USA, 253-259, 1987.

26. A.S. Campell, Thermodynamic Analysis of Combustion Engines, John Wiley\& Sons, New York, USA, 97-111; 261-279, 1986.

27. Z.H. Kodah, H.S. Soliman, M.A. Quadis, Z.A. Jahmany, Combustion In a SI Engine, Applied Energy, 66(3), 237-250, 2000.

28. O. Borat, A. Sürmen, M. Balc1, İçten Yanmalı Motorlar, Cilt 1, Uludă̆ Üniv. Vakfi Yayınları, İstanbul, Bursa, Ankara, 139-153; 249-259, 2000.

29. V. Ganesan, Internal Combustion Engines, McGraw-Hill Inc., USA, 135-149, 1996.

30. Y.A. Çengel, M.A.Boles, Thermodynamics-An Engineering Approach, McGraw-Hill Book Co., USA, 533-535, 597-601, 1989.

31. O. Borat, M. Balc1, A. Sürmen, Hava Kirliliği ve Kontrol Tekniği, 2. Bask1, Gazi Üniv. Teknik Eğitim Vakfı Yayınları, Ankara, 60-65, 1994.

32. E. Abu-Nada, I. Al-Hinti, B. Akash, A. Al-Sarkhi, Thermodynamic Analysis Of Spark-Ignition Engine Using a Gas Mixture Model For The Working Fluid, International Journal of Energy Research, 31, 1031-1046, 2007.

33. C.R. Ferguson, Internal Combustion Engines, John Wiley And Sons Inc., USA, 85-97; 115-128, 209-219, 1986.

34. R. Stone, Introduction to IC Engine, Macmillan Press Ltd., London, UK, 31-41; 142-151; 222-224; 428-433, 1999. 